\title{
Editorial: Global Crises, the Commons and Community Well-being
}

\section{WENDY HARCOURT}

There is no doubt we are dealing with multiple global crises: financial, food, fuel, climate and care. The media is full of catastrophic stories depicting increasing poverty and violence, insecurity and despair. Well-known British journalist Larry Elliot announced on the front page of The Guardian Weekly that 'capitalism is dying' (2009). We speak almost acceptingly of the cracks in the system, of our combustible times, of the menace just around the corner.We seem grimly aware that relentless economic growth is at odds with the viability of the planet but are somehow unable to stop it. Is it so impossible to go beyond business as usual? How can we move beyond fingerpointing? We can by all means criticize G20 governments, misplaced policies of economists, the greed of rich world consumers, the rapacious culture of transnational corporations and the environmental recklessness of 'fragile' states in their struggle to survive. But how do we look beyond to something more hopeful and more useful?

Those engaged in international development as practitioners, policymakers, advocates and intellectuals must take a hard look at some basic assumptions in development thinking and practice, which have aided and abetted the crises. Such self-criticism has to be based on faith and hope in human nature and human rights or we only add to the prevalent destructive discourse that leads to blaming others and little else. We have to avoid falling into the trap of neo-catastrophism that shifts the focus from what we want to what we fear.

There is after all much on which to build. To begin with, we can start to see altruism rather than selfishness and individual greed as the ruling principle of humanity. In contradiction to the received wisdom of media reports of looting, rapes and crime there are many less-known stories of positive human dynamics in the face of disaster (McKibben, 2009). In her recent book on twentieth century US-based natural disasters, Rebecca Solnit (2009) describes how most people in crisis situations are altruistic - caring for themselves and for those around them, strangers and neighbours as well as friends and loved ones. She argues that in the face of disaster it is public good rather private greed that triumphs. The prevailing response of humanity is imaginative, altruistic, communitarian and resourceful.

In going beyond business, as usual, we have to focus on positive qualities of humanity. That means underlining that solidarity and the search for connection is our default 
setting and that 'only the relentless privatization and consumerization of our lives in recent decades has convinced us otherwise' (McKibben, 2009: 52). What we need now is 'intellectual work about hope' that shows how [human] connection is important in this period of multiple crisis.

It is therefore extraordinarily important that the 2009 Nobel Prize in Economic Sciences went to Elinor Ostrom. Not only was she the first woman to receive the Noble Prize in economics, but her prize winning work is cross disciplinary and transnational. She has received other awards in political science, citizenship and public service. Her most famous work Governing the Commons (1990) shows how common resources such as forests, fisheries, oil fields or grazing lands can be managed successfully by the people who use them rather than by governments or private companies. ${ }^{1}$ Ostrom examines diverse institutional arrangements for managing natural resources with studies on the multifaceted nature of human-ecosystem interaction. Her findings on pasture management in West Africa and irrigation systems in the villages of Nepal fly in the face of the dominant theme of "the tragedy of the commons'. Ostrom illustrates how market privatization and top-down government control have adverse consequences for resource management, because they rob individuals of the capacity to govern themselves, and because they lead to the depletion of important forms of local collective knowledge. The production of common resources is more effective when owned and managed by collective institutions as they avoid overexploitation. She proposes collective choice arrangements, based on self-determination and multiple layers of enterprises scaling up from local communities.

Her work calling attention to the commons resonates with many development scholars who have also studied how humans interact with ecosystems and the need for respect for local communities' knowledge and customs that value sharing and care for others, indeed development abounds with such intellectual work about hope.

This first journal issue of volume 53 is devoted to building on that hope and insights for 2 new institutional frameworks for development.
Volume 53 as a whole revisits earlier wisdom and insights that have been submerged in the dominant mainstream of top-down government-led social change and marketization. The overall volume takes the title of 'Revisiting Human Development'. In doing so the editorial team acknowledges that for many years the journal has tried to see development as something more than economic growth. It has focused on values that go beyond greed and the profit motive in its discussion of human development, sustainable livelihoods, environment, culture and gender. The UNDP Human Development Report saw its early beginnings in the journal with the founder of the Report Mahbub ul Haq and his colleagues writing about human development. As the UNDP Report is celebrating 20 years through a process of assessment and rethinking, ${ }^{2}$ it seems appropriate for Development to engage readers in a critical debate on human development.

Overall, the journal will aim to raise some of the concerns around the concept and its relevance today. Despite its promise to put people at the centre of development in order to realize their choices and freedom, human development has been in many ways co-opted by the dominant mainstream that in the end put economic growth ahead of people's choices. Human development has been whittled down to competitive indexes and measurements of nations in the Human Development Index (HDI) and ultimately in the measurable goals of the Millennium Development Goals (MDGs). ${ }^{3}$ Following this first issue on new institutions for development, issue two looks at gender and the care crisis; issue three explores local economies and livelihoods; and the fourth issue examines new forms of education. In taking up these themes we hope to encourage and inform new types of conversations that offer fresh intellectual hope that will contribute to new values and new ways of doing development.

To begin the conversation the articles in this issue take up five main entry points.

The first is the critique on human development as a precursor to the MDGs as one thread of intellectual hope that has gone somewhat awry from the original grounding in human rights of the Millennium Declaration. There are several 
critiques particularly from young scholars in Asia and Africa of the limitations of the human development concept and its application through the MDGs. The second looks at development alternatives and the need to enlarge the concept of human development to encompass the commons or to link humanity, environment, culture and the biosphere and new community values. The articles in the thematic section outline where that debate is today. The third entry point is where real change is beginning to happen: in the exciting social experiments in Latin America that are changing institutions to bring about buen vivir 'living well'. Arturo Escobar's interview together with the lead article by Catherine Walsh and the articles in the dialogue section present readers buen vivir in praxis. The fourth entry point which will be taken up at length in the next issue of the volume, is the integral role that social reproduction and therefore women must play in the move towards collective well-being. The authors in the issue address gender in relation to understanding the impacts of transnational migration on economies, cultures and how it is played out in development. Lastly, the issue and the volume as a whole tries to promote new types of conversations that push far below the mainstream development models and blue prints, action plans and policy recommendations.

Perhaps the journal's most difficult task is to invite all of us engaged in development to admit the hypocrisy inherent within the system. We have to be brave enough to question how concepts such as human development, democracy, rights and freedom have been co-opted in the service of an extreme individualism that ignores the essential role of community and social reproduction without fear that the very questioning harms our work and prevents the possibilities to move towards a more participatory, just democratic global system. As Woodward and Hettne suggest in their articles the crises demand that we expose the existing system's promotion of corporate interests and geopolitical objectives by highlighting the immense human and environmental costs of the status quo. But we need to do it without undermining our own platform as we look for alternatives that change the very system in which we are working.
Such an endeavour resonates with Illich's earlier call for a counter research on fundamental alternatives to current prepackaged solutions' (Illich, 1971).

Development has aimed to raise these questions for many years. The search for alternatives has characterized the journal's editorial line, beginning with the editorship of Wolfgang Sachs in the 1980s. As Raghuram in her interview and Ramirez and Quarry remind us in their article there has been a shared vision of intellectual hope in this search that the eradication of poverty is endogenous and self-reliant building on the strengths of the people in their societies. Such change also needs to be in harmony with the environment. And here the commons, sharing with community and nature features prominently.

Esteva's article describes the debate and the movement around the commons in detail. The commons and how to move from private ownership was being discussed in the 1980s by peasants, urban marginal and intellectuals who disconnected themselves from the dominant development institutions. In his influential book Gender Ivan Illich in 1982 describes the alliance of that time as:

\footnotetext{
...Those who struggle to preserve the biosphere, and those who oppose a style of life characterized by a monopoly of commodities over activities, by reclaiming in bits and pieces the ability to exist outside the market's regime of scarcity, have recently begun to coalesce in a new alliance. The one value shared by all currents within this alliance is the attempt to recover and enlarge, in some way, the commons. (Illich, 1982)
}

Esteva, Riggirozzi, Eversole and Walsh describe the resurgence of this value in the Latin American experiments of buen vivir (living well). Although one word cannot express the rich diversity of social struggles in Latin America buen vivir refers to new ways of life, new forms of constitutional rules and of government. In her lead article, Catherine Walsh suggests there is much hope but also illusions, tensions and contradictions around buen vivir. The articles tell of exciting and hopeful experiences particularly in Ecuador where new institutional arrangements that go beyond 
Eurocentric modernity are being put into place. In Ecuador the cosmovision of the indigenous peoples of Abya Yala of Pachamama, of Mother Earth is enshrined in the Political Constitution of Ecuador, in October 2008. How to put the culture of nurturing life and the communitarian vision into practice needs further scrutiny. Walsh warns us that woven into Ecuadorian governance, she detects the familiar Eurocentric paradigms of human sustainable development. Nevertheless, what is happening in some parts of Latin America are real alternatives to a development based on economic growth, narrow individualism and exploitation of nature. It reflects connections with others and values such as complementarity, reciprocity and communitarianism, which are far closer to the global ethics towards which Björn Hettne asks that we strive. ${ }^{4}$

Another sign of hope that values and institutions are changing towards more connection and harmony is the concerted efforts to end gender bias in development. From being an invisible subject, all people's rights, but in particular women's rights, in development have become a multilayered campaign for change. It moves us closer to a world where women's lived experiences are acknowledged and women are perceived as full and active economic and social actors who, in this complex crises-ridden world, lead in caring for families and communities. Caribbean feminist Peggy Antrobus, for example has pointed out how despite the Caribbean history of colonialism, enslavement, indentured labour, migration and violence, people survived by creating the new families and communities. The majority of these families were headed by women driven by values and imagination of mutual sharing and caring. The Caribbean culture has stretched across the globe where 'Caribbean people know that what enables us to survive is not only money but the relationships we have with each other: the mutual support, the reciprocity, all the gifts we give each other each day for which there is no financial equivalent' (Antrobus, 2009).

And a fifth entry point is that like the women from the Caribbean, we need to use our imagination and creativity to create ways forward that changes in World Bank policy, new MDGs after 2015, more and better human development, endless reports and hollow statements of intent. What we need is new types of conversations that multiply and merge Eurocentric, capitalist, modern and non-Western indigenous cosmovisions into different kinds of conversations, languages and practices. The new institutions framing development cannot be delivered by impersonal structures whether vertical or horizontal, they have to be a fluid part of our ways of working, sharing and communications. Today's multimedia, communication technologies offer such possibilities. We need to take up the challenge to blend the different knowledges of science, economies, politics, ecologies and humanities in ways that shape different connections than ones that are binary and oppositional.

To take one example the issue of violence against women. Breaking silences around rape and violence is now on the UN agenda. The UN Resolution 1820 against the violation of women's bodies in war recognizes rape of girls, boys and women in war and its aftermath as international security issue ${ }^{5}$ crime against humanity. In media rape is almost so common it is old news even as it is happening. But rightly, the stories keep being told, about the rape, sexual trafficking, child brides, the killings in Maquiladoras in Mexico as Arizpe in her interview recalls. Such gender inequality is so huge it requires global campaigns for legislation and punishment. However, it is important that women are not perceived solely as violated victims needing to be rescued. This keeps the gender hierarchies intact. We need to underscore that their care and work in the household, the community and environment are crucial. As Mohammed Yunus, the Nobel Peace Prize winner has convinced many thousands around the world, it is women who invest their time and earnings in their families, education, housing and health, whereas men are more likely to spend it on themselves (Halpern, 2009). When societies evolve in ways that leave men with no constructive role, they are very good at embracing destructive roles. It is important to revalue women's work including excessive differentiation of gender roles. Not only in the South but also in the North. For example, in 
the US, radical homemaking (Hayes, 2009) is taking off, which promotes both men and women's care roles in families and communities. We need to provide structural and institutional change so that women (and men) overcome gender inequalities in the family, community and in the space of public governance.

It is difficult to have new conversations when many of us are caught within narrow ways of thinking. For example, at the launch of Development volume 52 no 3 'Beyond Economics' held in October 2009, participants at one point seemed divided into two diametrically opposed views of feminism. On one side there was a proposal for radical homemaking as something feminists could do in order to balance nature, community and family life by moving away from the rat race and back to local economies. This proposal was greeted with bemusement by other participants who were at pains to point out that this was not a solution for most women where gender relations in the home were often exploitative and led to high levels of violence, as the frightening statistics on domestic violence attest. We need to find language to reject the individualism of consumerist and global capitalism without denying individual autonomy and rights.

To quote Peter Block ${ }^{6}$ 'The way we create conversations that overcome the fragmented nature of our communities is what creates an alternative future. ... We cannot problem solve our way into fundamental change, or transformation. We need to shift the context and language within which problem solving takes place and change our idea of what constitutes action'.

I hope volume 53 proves a vital part of this shift.

\section{Notes}

1 See www.en.wikipedia.org/wik/elninor.ostrom, accessed 20 November 2009

2 See the 'Collections on Human Development' www.sidint.org development, which assembles some of the latest thinking on human development in the journal as well as this issue of 'Last Word', which announces the process of rethinking by UNDP http://hdr.undp.org/en/reports/global/hdr2010/, accessed 18 November 2009.

3 See the description of the 2009 Human Development Report and its themes over the years (poverty, gender, democracy, human rights, cultural liberty, globalization, water scarcity, climate change, migration at http://hdr .undp.org/en/reports/global/hdr2009/, accessed 20 November 2009.

4 See the discussion by Katu Arkonada 'Civilisation Crisis and Living Well', posted 20/10/2009 http://www.icae2 .org/?q = en/node/1040, accessed 20 November 2009.

5 See the statement by Ines Alberdi, Executive Director, UNIFEM for UN International Day for the Elimination of Violence Against Women 'the issue of violence against women and girls is no longer treated as simply a woman's concern [it is] a human rights issue, a peace and security issue, and an issue of urgent concern to both men and women'. http://www.unifem.org/news_events/story_detail.php?StoryID = 976, accessed 25 November 2009.

6 See 'Civic Engagement and the Restoration of Community: Changing the Nature of the Conversation' by Peter Block http://www.asmallgroup.net/pages/images/pages/CES.jan2007.pdf, accessed 21 November 2009.

\section{References}

Antrobus, Peggy (2009) 'What About Gender Issues', posted 20/10/2009 http://www.icae2.org/?q = en/node/1040, accessed 20 November 2009.

Elliott, Larry (2009) 'The Capitalist Dream is Dying a Painful Death', The GuardianWeekly, 6-12 November, pp 1-3.

Halpern, Sue (2009) 'Breaking a Conspiracy of Silence', New York Review of Books, 19 November, pp 33-37.

Hayes, Shannon (2009) Radical Homemakers Reclaiming Domesticity from a Consumer Culture, Richmondsille, NY: Left to Write Press.

Illich, Ivan (1971) Celebration Of awareness: A call for institutional revolution, New York: Harper and Row.

Illich, Ivan (1982) Gender, New York: Pantheon Books.

McKibben, Bill (2009) 'In the Face of Catastrophe a Surprise', New York Review of Books, 5 November, pp 50-52.

Ostrom, Elinor (1990) Governing the Commons, Cambridge: Cambridge University Press.

Solnit, Rebecca (2009) A Paradise Built in Hell:The extraordinary communities that arise in disaster, New York: Viking. 